\title{
Anatomy, physiology and drugs triangular dynamics in Steven Johnsons syndrome
}

\begin{abstract}
The incidence of Steven-Johnson syndrome has been on the increase within the last two years in Nigeria. This renewed the interest on this disease to explore the dynamics for improved patient care. This review outlined the relationship between anatomic or structural changes, physiological variations, and the effect of drugs in Steven Johnson's syndrome. Better understanding of the fundamental structural and physiological changes in affected patients is vital to improve the treatment and/or the initial management procedures in resource-limited environments. This article showed the relationship between structural features, functions, and treatment. Tailoring treatment to the anatomical, physiological changes, and the effect of drugs and causative agents suggests a triangular dynamic trend in the disease state management.
\end{abstract}

Keywords: epidermal cells, necrolysis, drugs, membranes, steven johnsons syndrome
Volume 4 Issue 3 - 2017

\author{
Ogbonna Brian O \\ Department of Clinical Pharmacy and Pharmacy Management, \\ Nnamdi Azikiwe University, Nigeria
}

\begin{abstract}
Correspondence: Ogbonna Brian O, Department of Clinical Pharmacy and Pharmacy Management, Faculty of Pharmaceutical Sciences, Nnamdi Azikiwe University, Awka, Nigeria, Tel +2348037794206, Email yokoyama.megumi02@nihon-u.ac.jp
\end{abstract}

Received: May 02, 2017 | Published: September 21, 2017

\section{Introduction}

Stevens-Johnson syndrome, (SJS) is a life-threatening skin disorder characterized by toxic epidermal necrolysis, in which cell death causes the epidermis to detach from the dermis. The syndrome is a hypersensitivity complex that affects the skin and the mucous membranes. The syndrome is causes are certain medications (such as lamotrigine), but it can also be due to infections, or more rarely, cancers, or hypersensitivity reaction to some compounds. ${ }^{1,2}$ The blisters and erosions in SJS cover between $3 \%$ and $10 \%$ of the entire body surface. ${ }^{3}$ It is associated with factors ranging from immunoreactions, infections, genetic factors, and adverse drug reactions. ${ }^{4,5}$ Immunocompromised patients who are slow acetylators and brain tumor patients on anticonvulsant drugs who are undergoing radiotherapy are usually more prone to SJS. ${ }^{6}$

The incidence is estimated at 1.1 and 7.1 cases per million per year and higher in Africa due to high use of crude drugs and HIV prevalence. ${ }^{7}$ Better understanding of the fundamental structural and physiological changes in affected patients is essential towards improving the treatment and/or the initial management procedures in resource-limited environments. This article simplified and brought to the fore the relationship between anatomic structure, physiology, and causes of SJS, which could be utilized in resource, limited settings in patients management. It showed the relationship between structural features, functions, and treatment. t, $, 8,8$ This review outlined the relationship between anatomic or structural changes, physiological variations, and the effect of drugs in Steven Johnson's syndrome.

\section{Discussion}

The manifestation of SJS is usually multifaceted affecting varying degree of body surfaces and structures. Treatments are usually merely supportive, symptomatic, and dependent on the percentage of body surface, the structures affected, and the degree of damage done to the affected structures. ${ }^{10}$ Following generalized cellular deterioration accompanying the disease process, damaging cellular effects can take place at the tissue levels precipitating depression of mitochondrial activities, reduction of sodium and potassium transport across cell membranes leading to accumulation of sodium and chlorides in the cells and loss of potassium and subsequent swelling of cells. Lysosomal activities ensue leading to intracellular deterioration. ${ }^{11}$ Cells adjacent to venous end of capillaries with can suffer nutritive deficiency. This can lead to tissue necrosis in severe shock. Cardiac output and arterial pressure often decrease in anaphylactic conditions leading to the release of histamine and histamine like substances with a net effect of reduction in mean venous return and its catastrophic consequences. ${ }^{12}$ Epithelial tissues cover body surfaces, line the cavities, and serve as interface tissue for protection, absorption, excretion, filtration, sensory perception, and secretion. These anatomical and physiological functions are altered to varying degrees in SJS.

Disruption of this structure and function lead to loss of body fluids containing proteins and electrolyte. Dehydration and electrolyte imbalance ensues leading to further alteration of homeostasis. This forms one of the bases of therapy. Microorganisms multiply rapidly in the nutrient-rich structures dead and protein rich body fluid bathedtissues. Infection threats associated with loss of skin barrier. This forms the basis for antibiotic use in therapy. ${ }^{13}$ Other signs and symptoms in SJS are associated with structural and physiological defects, which disrupt normal physiological mechanisms as shown in Table 1. Additional physiological and pathophysiological manifestations include fatigue, fever, and sore throat. The pathophysiological manifestations form the basis of management, employed in patient management in resource-limited settings. The management procedures will depend on the degree of manifestation, percentage of body surface affected, causes and other presenting signs and symptoms. ${ }^{5,14}$ Other treatment modalities based on prompt recognition of causative agents and organisms as shown in Table 2. Retrospective studies suggested that use of corticosteroids is controversial because of associated increase in hospital stay and resultant increase in complication rates. The use of cyclophosphamides and cyclosporins did not offer better therapeutic outcomes. Use of antiseptics and topical anesthetics is very common and essential in resource-limited settings. Ophthalmological team should be invited or consulted in corneal vascularization and other ophthalmic complications. ${ }^{15-18}$

Erythema multiforme major (EMM) is different from SJS despite their similarities. This was clearly delineated in 1993. ${ }^{19,20}$ Studies have shown that antibiotics, anticonvulsants, and NSAIDS trigger 
SJS very often. ${ }^{19,21}$ However, drug induced SJS has been poorly reported. ${ }^{22}$ Report by Stevens Johnson Syndrome foundation (SJSF), has shown that commonly used over-the-counter medications like paracetamol, amoxicillin, and ibuprofen, and herbal products with Ginseng can trigger SJS and TEN. ${ }^{23,24}$ SJS has been tailored to viral and Mycoplasma pneumonia without previous sensitization. ${ }^{19,25-30}$ Studies in immunicompromized patients show that they are more susceptible to SJS. ${ }^{18,30-35}$ This suggests genetic inclination to the varying manifestations of SJS. ${ }^{36}$ Immunoglobulin preparations administered intravenously showed good outcomes in reduction of the duration of skin reactions and reduction of pathophysiological manifestations like symptoms. ${ }^{37-39}$ Discontinuation of triggering substances and use of high dose corticosteroids has shown promising outcomes in therapy. ${ }^{40}$ Adjuvant therapy like plasmapheresis has been beneficial in SJS cases. ${ }^{41-46}$

Table I Relationship between Anatomical basis and Physiological/pathophysiological manifestations of SJS

\begin{tabular}{|c|c|c|}
\hline Timing & Anatomical basis & Physiological/pathophysiological manifestations \\
\hline \multirow{4}{*}{ Early stage } & Basket weave-like stratum corneum & Full-thickness epidermal necrosis \\
\hline & Dermis and epidermis & $\begin{array}{l}\text { Fever, sore throat, running nose, fatigue, general aches and pains, ulcers in mouth, } \\
\text { genitals, anal regions as well as conjunctivitis }\end{array}$ \\
\hline & Confluent epidermal necrosis & Minimal associated inflammation \\
\hline & $\begin{array}{l}\text { Death of keratinocytes, less than } 10 \% \\
\text { external epidermal detachment }\end{array}$ & Separation of the epidermis from the dermis \\
\hline \multirow{6}{*}{$\begin{array}{l}\text { Advanced } \\
\text { stage }\end{array}$} & DNA disorganization & Recruitment of more chemokines from dieing cells \\
\hline & Erythematous, flat and purpuric lesions & $\begin{array}{l}\text { Pigmentation problems, skin scarring, scarred genitals, joint pains, lung diseases, } \\
\text { obstructive disorders and eye complications, adhesions, ulcers, and blindness. }\end{array}$ \\
\hline & Epidermal necrolysis & Inflammation of epidermal cells and death of affected cells \\
\hline & Dehydration & Thromboembolism and disseminated intravascular coagulation \\
\hline & \multirow{2}{*}{$\begin{array}{l}\text { Gastrointestinal ulceration, necrolysis, } \\
\text { strictures and perforation }\end{array}$} & Acute malnutrition \\
\hline & & Shock and multi-organ failure \\
\hline
\end{tabular}

Table 2 Relationship between the likely causes of SJS, pathophysiological changes, and likely interventions

\begin{tabular}{|c|c|c|c|c|}
\hline $\begin{array}{l}\text { Implicated } \\
\text { organisms }\end{array}$ & Implicated ilnfections & $\begin{array}{l}\text { Implicated } \\
\text { drugs/agents }\end{array}$ & Pathophysiological changes & Likely interventions \\
\hline Protozoa & $\begin{array}{l}\text {-Herpes (herpes simplex or } \\
\text { herpes zoster); } \\
\text {-Pneumonia } \\
\text {-HIV } \\
\text {-Hepatitis } \\
\text {-Mumps } \\
\text {-Influenza } \\
\text { Coxsackie virus } \\
\text {-Epstein-Barr virus } \\
\text {-Enteroviruses } \\
\text {-Group A beta-hemolytic } \\
\text { streptococci, diphtheria, } \\
\text { Mycoplasma pneumoniae, } \\
\text { lymphogranuloma venereum, } \\
\text { mycobacteria, rickettsial } \\
\text { infections, tularemia, brucellosis, } \\
\text { and typhoid } \\
\text {-Dermatophytosis, and } \\
\text { histoplasmosis have been } \\
\text { considered as possible causes } \\
\text { of SJS }\end{array}$ & $\begin{array}{ll}\text { - } & \text { Analgesics } \\
& \text { Allopurinol, } \\
\text { Acetaminophen } \\
\text { Antibiotics } \\
\text { Penicillin, } \\
\text { - } \quad \text { Antipsychotics } \\
\text { - } \quad \text { Sulfiation therapy } \\
\text { Trimethoprim- } \\
\text { sulfamethoxazole } \\
\text { Sulfadiazine } \\
\text { Sulfasalazine } \\
\text { Antiviral agents: } \\
\text { Nevirapine } \\
\text { Abacavir } \\
\text { Anticonvulsant: } \\
\text { Phenobarbital } \\
\text { Phenytoin } \\
\text { Valproic acid } \\
\text { Carbamazepine } \\
\text { Lamotrigine } \\
\text { Imidazole antifungal } \\
\text { agents } \\
\text { Non-steroidal anti- } \\
\text { inflammatory drugs } \\
\text { (oxicam type such } \\
\text { as meloxicam). } \\
\text { Salicylates } \\
\text { Sertraline } \\
\text { Bupropion }\end{array}$ & $\begin{array}{l}\text {-Corneal vascularization } \\
\text {-Mouth ulcer } \\
\text {-Mucosal involvement: erythema, } \\
\text { oedema, sloughing, blistering, } \\
\text { ulceration and necrolysis. } \\
\text {-Eye: conjunctivitis, corneal } \\
\text { ulcerations. } \\
\text {-Genital: erosive vulvovaginitis or } \\
\text { balanitis } \\
\text {-General examination: fever, } \\
\text { tachycardia, hypotension; altered } \\
\text { level of consciousness, seizures, } \\
\text { coma. } \\
\text {-Skin: Lesions may occur } \\
\text { anywhere, non pruritic urticarial } \\
\text { lesions } \\
\text {-Lung: mucosal shedding } \\
\text {-Vaginal stenosis and penile } \\
\text { scarring } \\
\text {-Renal tubular necrolysis and } \\
\text { acute kidney injury may occur } \\
\text {-Gastrointestinal ulceration }\end{array}$ & $\begin{array}{l}\text {-Cessation of suspected } \\
\text { drugs } \\
\text {-Hospital Admission: } \\
\text { Preferably in burns unit/ } \\
\text { intensive care } \\
\text {-Nutritional and fluid } \\
\text { replacement } \\
\text {-Temperature } \\
\text { maintenance } \\
\text {-Pain relief } \\
\text { Skin care } \\
\text {-Antitetanus prophylaxis } \\
\text {-Antihistamines } \\
\text {-Mouth-care } \\
\text { Cyclophosphamide and } \\
\text { cyclosporin } \\
\text {-Intravenous } \\
\text { immunoglobulin } \\
\text {-Topical pain anaesthetics } \\
\text { and antiseptics, } \\
\text {-Nasogastric or } \\
\text { parenteral feeding } \\
\text {-Oral macrolide or oral } \\
\text { doxycycline }\end{array}$ \\
\hline
\end{tabular}




\section{Conclusion}

Disruption of physiological functions in SJS is associated with resultant alteration in structural/anatomical functions leading to myriads of clinical manifestations associated with the disease state. These manifestations form the basis for management of SJS, utilized in resource-limited settings where specialist care and equipment are non-accessible. Simple understanding of the anatomical and pathophysiological basis, and subsequent selection of treatment options based on the underlying cause and degree of progression could be a vital means of averting its progression to critical states and subsequent loss of lives especially in developing countries. Tailoring treatment to the anatomical, physiological changes, and the effect of drugs and causative agents suggests a triangular dynamic trend in the disease state management. Disease process is a dynamic one. Saving lives should be paramount before accessing specialist care especially in places where immediate specialist care could not be imminent. Elimination of all suspected agents and drugs, fluid replacement where possible and microbial protection with antibiotics based on clinicians discretion is vital to arresting further disease progression, restoring normal physiological functions and ultimately saving lives in remote and resource limited settings before referral for specialist care.

\section{Acknowledgements}

None.

\section{Conflict of interest}

Author declares that there is no conflict of interest.

\section{References}

1. Ward KE, Archambault R, Mersfelder TL. Severe adverse skin reactions to non-steroidal anti-inflammatory drugs: A review of the literature. $\mathrm{Am}$ J Health Syst Pharm. 2010;67(3):206-213.

2. Mockenhaupt M. The current understanding of Stevens-Johnson syndrome and toxic epidermal necrolysis. Expert Rev Clin Immunol. 2011;7(6):803-815.

3. Tan SK, Tay YK. Profile and pattern of Stevens-Johnson Syndrome and toxic epidermal necrolysis in a general hospital in Singapore: Treatment outcomes. Acta Derm Venereol. 2012;92(1):62-66.

4. Sassolas B, Haddad C, Mockenhaupt M, et al. ALDEN, an algorithm for assessment of drug causality in Stevens-Johnson Syndrome and toxic epidermal necrolysis: Comparison with case-control analysis. Clin Pharmacol Ther. 2010;88(1):60-68.

5. Surovik J, Riddel C, Chon SY. A case of bupropion-induced StevensJohnson syndrome with acute psoriatic exacerbation. J Drugs Dermatol. 2010;9(8):1010-1012.

6. Lonjou C, Borot N, Sekula P, et al. A European study of HLA-B in Stevens-Johnson syndrome and toxic epidermal necrolysis related to five high-risk drugs. Pharmacogenet Genomics. 2008;18(2):99-107.

7. Pharmacists confirm Steven Johnson Syndrome in Nigeria. 2017.

8. Fritsch P. European Dermatology Forum: skin diseases in Europe. Skin diseases with a high public health impact: toxic epidermal necrolysis and Stevens-Johnson syndrome. Eur J Dermatol. 2008;18(2):216-217.

9. Phillips EJ, Chung WH, Mockenhaupt M, et al. Drug hypersensitivity: pharmacogenetics and clinical syndromes. J Allergy Clin Immunol. 2011;127(3 Suppl):S60-S66.

10. Grander DN, Stokes KY, Shigematus T, et al. Splanchnic ischaemiareperfusion injury Mechanistic insights provided by mutant mice. Acta Physiol Scand. 2001;173(1):83-91.
11. Ledgerwood AM, Lucas CE. A review of studies on the effects of hemorrhagic shock and resuscitation on the coagulation profile. $J$ Trauma. 2003;54 (Suppl 5):S68-S74.

12. River E, Nguyen B, Havstad S, et al. The early goal directed therapy collaborative group. Early goal directed therapy in treatment of severe sepsis and septic shock. N Eng J Med. 2001;345(19):1368-1377.

13. Marieb ERN. Tissue: the living fabric. Human anatomy and physiology. USA: Benjamin/Cummings Science Publishing; 1998. p. 109-138.

14. Kocak S, Girisgin SA, Gul M, et al. Stevens-Johnson syndrome due to concomitant use of lamotrigine and valproic acid. Am J Clin Dermatol. 2007;8(2):107-111.

15. Man CB, Kwan P, Baum L, et al. Association between HLA-B*1502 allele and antiepileptic drug-induced cutaneous reactions in Han Chinese. Epilepsia. 2007;48(5):1015-1018.

16. Ciralsky JB, Sippel KC, Gregory DG. Current ophthalmologic treatment strategies for acute and chronic Stevens-Johnson syndrome and toxic epidermal necrolysis. Curr Opin Ophthalmol. 2013;24(4):321-328.

17. Hinc Kasprzyk J, Polak Krzemińska A, Ożóg Zabolska I. Toxic epidermal necrolysis. Anaesthesiol Intensive Ther. 2015;47(3):257-262.

18. Mittmann N, Knowles SR, Koo M, et al. Incidence of toxic epidermal necrolysis and Stevens - Johnson syndrome in an HIV cohort: an observational, retrospective case series study. Am J Clin Dermatol. 2012;13(1):49-54.

19. Waleed MS (2017) Bibliometric analysis of literature on toxic epidermal necrolysis and Stevens-Johnson syndrome: 1940-2015. Orphanet J Rare Dis. 2017;12(1):14.

20. Tomasini C, Derlino F, Quaglino P, et al. From erythema multiforme to toxic epidermal necrolysis. Same spectrum or different diseases? $G$ Ital Dermatol Venereol. 2014;149(2):243-241.

21. Hur J, Zhao C, Bai JP. Systems pharmacological analysis of drugs inducing stevens-johnson syndrome and toxic epidermal necrolysis. Chem Res Toxicol. 2015;28(5):927-934.

22. Goldblatt C, Khumra S, Booth J, et al. Poor reporting and documentation in drug-associated Steven Johnson syndrome and toxic epidermal necrolysis-lessons for medication safety. Br J Clin Pharmacol. 2017;83(2):224-226

23. Khawaja A, Shahab A, Hussain SA. Acetaminophen induced Steven Johnson syndrome-toxic epidermal necrolysis overlap. JPMA J Pak Med Assoc. 2012;62(5):524-527.

24. Foundation SJS. SJS Fact Sheet. 2016.

25. Aihara Y, Ito S, Kobayashi Y, et al. Stevens-Johnson syndrome associated with azithromycin followed by transient reactivation of herpes simplex virus infection. Allergy. 2004;59(1):118.

26. Duarte AF, Cruz MJ, Moreira E,et al. Stevens Johnson syndrome/ erythema multiforme major and Chlamydia pneumoniae infection in young patients. Dermatol Reports. 2010;2(1):e6.

27. Ahluwalia J, Wan J, Lee DH, et al. Mycoplasma-associated StevensJohnson syndrome in children: retrospective review of patients managed with or without intravenous immunoglobulin, systemic corticosteroids, or a combination of therapies. Pediatr Dermatol. 2014;31(6):664-649.

28. Wang L, Hong KC, Lin FC, et al. Mycoplasma pneumoniae-associated Stevens-Johnson syndrome exhibits lymphopenia and redistribution of CD4+ T cells. J Formos Med Assoc. 2003;102(1):55-58.

29. Campagna C, Tassinari D, Neri I, et al. Mycoplasma pneumoniae induced recurrent Stevens-Johnson syndrome in children: a case report. Pediatr Dermatol. 2013;30(5):624-626. 
30. Wanat KA, Castelo Soccio L, Rubin AI, et al. Recurrent StevensJohnson syndrome secondary to Mycoplasma pneumoniae infection. Cutis. 2014;93(4):E7-E8.

31. Yunihastuti E, Widhani A, Karjadi TH. Drug hypersensitivity in human immunodeficiency virus-infected patient: challenging diagnosis and management. Asia Pac Allergy. 2014;4(1):54-67.

32. Dziuban EJ, Hughey AB, Stewart DA, et al. Stevens-Johnson syndrome and HIV in children in Swaziland. Pediatr Infect Dis J. 2013;32(12):1354-1358.

33. Yang C, Mosam A, Mankahla A, et al. HIV infection predisposes skin to toxic epidermal necrolysis via depletion of skin-directed CD4(+) T cells. J Am Acad Dermatol. 2014;70(6):1096-1102.

34. Dube N, Adewusi E, Summers R. Risk of nevirapine-associated Stevens-Johnson syndrome among HIV-infected pregnant women: the Medunsa National Pharmacovigilance Centre, 2007-2012. S Afr Med J. 2013;103(5):322-335

35. Viswanath BK, Ranka P, Ramanjanayalu M. Severe cutaneous adverse reactions due to isoniazid in a HIV positive patient. Indian $J$ Lepr. 2012;84(3):227-232.

36. Pirmohamed $\mathrm{M}$, Arbuckle JB, Bowman $\mathrm{CE}$, et al. Investigation into the multidimensional genetic basis of drug-induced StevensJohnson syndrome and toxic epidermal necrolysis. Pharmacogenomics. 2007;8(12):1661-1691.

37. Aihara M, Kano Y, Fujita H, et al. Efficacy of additional i.v. immunoglobulin to steroid therapy in Stevens-Johnson syndrome and toxic epidermal necrolysis. J Dermatol. 2015;42(8):768-777.

38. Vazquez Sanabria IL, Mercado Seda R, Varela Rosario N, et al. Efficacy of intravenous immunoglobulins in a patient with systemic lupus erythematosus presenting with Stevens-Johnson syndrome. BMJ Case Rep. 2015.
39. Boroda K, Li L, Riina L, et al. Cephalosporin-Induced Toxic Epidermal Necrolysis Treated with Intravenous Immunoglobulin. Cureus. 2015;7(10):e359.

40. Gupta LK, Martin AM, Agarwal N, et al. Guidelines for the management of Stevens-Johnson syndrome/toxic epidermal necrolysis: An Indian perspective. Indian J Dermatol Venereol Leprol. 2016;82(6):603-625.

41. Mahale R, Chetan G, Sagar H, et al. Plasmapheresis as an adjuvant treatment modality in toxic epidermal necrolysis: A case report. $J$ Clin Diagn Res. 2011;5(1):107-108.

42. Yamada H, Takamori K. Status of plasmapheresis for the treatment of toxic epidermal necrolysis in Japan. Ther Apher Dial. 2008;12(5):355-359.

43. Narita YM, Hirahara K, Mizukawa Y, et al. Efficacy of plasmapheresis for the treatment of severe toxic epidermal necrolysis: Is cytokine expression analysis useful in predicting its therapeutic efficacy? $J$ Dermatol. 2011;38(3):236-245.

44. Szczeklik W, Nowak I, Seczynska B, et al. Beneficial therapeutic effect of plasmapheresis after unsuccessful treatment with corticosteroids in two patients with severe toxic epidermal necrolysis. Ther Apher Dial. 2010;14(3):354-357.

45. EMA. Orphan Drugs and Rare Diseases at a Glance. 2017.

46. Orpha data. Rare Diseases Epidemiological Data. 2017. 